\title{
On the Political: A Comparative Political Thought Speculation
}

\section{Catus Brooks*}

Department of Humanities, University of Victoria, British Columbia, Canada

*Corresponding author: Catus Brooks, Professor, Department of Humanities, University of Victoria, British Columbia, Canada, Tel: 1-250-721-7211; E-mail: sirgraciousness@gmail.com

Received date: March 12, 2018; Accepted date: March 21, 2018; Published date: March 28, 2018

Copyright: $\odot 2018$ Brooks C. This is an open-access article distributed under the terms of the Creative Commons Attribution License, which permits unrestricted use, distribution, and reproduction in any medium, provided the original author and source are credited.

\begin{abstract}
When reflecting on the political in comparative political thought (CPT), it is unnecessary "to define just what 'the political' actually is". For, "the question 'what is the political?"' can be best answered with a treatise, which is beyond our present inquiry. What progress can be made, we argue, lies in inductively analyzing the political phenomenon of pacifism. For, by specifically analyzing pacifism, we may draw generalizations relevant to sovereign decisionmakers. We used the term sovereign because questions regarding violence belong especially to sovereigns over a state, for rest content that a state has the monopoly over violence.Further, by making pacifism the subject of this speculation, assumptions regarding militarization become questionable. If political science's foremost purpose is to regulate matters of war and the use of force, questions of pacifism must follow and assumptions of militarism must be suspected. In this inquiry, it will suffice to only go over theories of pacifism from Greek and Indian political thought. We are shooting to juxtapose pacifism from Greek ourthology and Mahatma Gandhi's Hind Swaraj or Indian Home Rule. For, at the very least, this will assist sovereigns in deciding upon political questions, like the appropriate spirit towards violence. To begin, we must define the meanings of pacifism, militarism, and the use of force. But, it is not enough to merely touch on pacifism in the context of Greek ourthology and Gandhi's political thought, we must also compare the two in hope of better informing sovereign decision-makers. The above-said will serve as a plan for this essay.
\end{abstract}

Keywords: Humanity; Arts; Social; Politics

\section{Introduction}

In political science, pacifism is a highly technical term, needing clarification. Rebecca Carhart states, "pacifism can be generally defined as an ethical theory that holds the use of force to be morally impermissible". The equation of pacifism is not this simple though, as moral questions about it involve extensive reasoning. One point is clear however, the starting-point in these considerations begins with the use of force being intolerable. From there, one may decide when and how much force would be appropriate, if at all, in a given situation. Nonetheless, what must be ruled out is that the philosophy of pacifism entails absolute disallowance of force. Some pacifists may decide such, but this, we argue, is a more extreme view. In this essay, we will be mainly dealing with more moderate understandings of pacifism, which accept the use of force conditionally [1-5].

For our part, we must distinguish between the use of force and militarization. By use of force, we mean not only force in war, but also the force used by states against non-state actors and the force of nonstate actors against other non-state actors. A state essentially means a polity and a non-state actor ranges from organizations to individuals. Distinct from the use of force, militarization is the imbuing of militarism, the conflating of affairs to make them military, and the preparing for armed conflict or war [6]. Further, militarism is "the principle or policy of maintaining a large military establishment" [7]. Militarism also entails "the tendency to regard military efficiency as the supreme ideal of the state and to subordinate all other interests to those of the military" [7]. Thus, as an emphatic note, the use of force does not implicate militarism or militarization. Nonetheless, pacifism stands opposed to militarism, as the former does not idealize military efficiency nor prioritize military interests, but holds even just the use of force as subject to ethical scrutiny. These specifications are the groundwork for the comparisons and reflective inductions that follow.

Next, the philosophy of pacifism can be understood from the Greek poetry of Homer, namely The Iliad and The Odyssey. Both Pallas Athene and Ares are war deities, and Pallas Athene is the Greek name for Athena. The discrepancy between the two, however, is that the former prefers pacifism while the latter is associated with brutal forms of war [8]. This is demonstrated by The Iliad, where one of Homer's motifs is Athene's superiority in warfare over Ares. Stanley Lombardo in translating The Iliad writes [9]:

And Zeus, from under thunderhead brows: "shifty lout. Don't sit here by me and whine. You're the most loathsome god on Olympus. You actually like fighting and war. You take after your hardheaded mother, Hera. We can barely control her either... Be that as it may, we cannot tolerate you're being in pain..." And he called Paieon to doctor his wound... Then back to the palace of great Zeus came ... Athena the protector, having stopped brutal Ares from butchering men.

\section{Review Strategy}

Here, Zeus is judging Ares immediately after he has lost a battle to Athene, hence Homer's depiction of Ares' injured condition and his glorification of Athene as a protector. Further, with such a word as butchering associated with Ares in this quote, he is depicted as a brute. Moreover, Zeus' judgement, "you actually like fighting and war", marks Ares as a warmonger. But perhaps the greatest lesson to draw from this allegory, which in this context is a poem that represents a greater moral, is that Ares is loathsome for enjoying war, especially as he suffers defeat, meanwhile Athene is victorious, simply as a protector. 
(10.417/2151-6200.1000354

Page 2 of 3

But to reflect on pacifism still this is not enough, as the above-quote is a mere orientation of Athene's pacific character.

Thus, in inducing from pacifism to generalizations on the political, we must continue to build on the character of Athene. We turn to Robert Graves' "Athene's Nature and Deeds" [10], although a goddess of war, she gets no pleasure from battle, as Ares and Eris do, but rather from settling disputes, and upholding the law by pacific means. She bears no arms in time of peace and, if ever she needs any, will usually borrow a set from Zeus. Her mercy is great: when the judges' votes are equal in a criminal trial at Areiopagus, she always gives a casting vote to liberate the accused. Yet, once engaged in battle, she never loses the day, even against Ares himself, being better grounded in tactics and strategy than he; and wise captains always approach her for advice.

Similar to what we said regarding Homer's depiction of Ares from the last paragraph, Graves states that Athene, in contrast to Ares, derives no pleasure from battle. Graves states that she does statecraft pacifically, but if she needs arms she will borrow them. This metaphor means to me that warfare is not preferable, but that pacifism does not mean to lack military recourse. For, pacifism does not imply utter defenselessness, as even pacific Athene would recourse to defensive measures if expedient. The above-said accounts for Athene's pacific nature.

What is next to treat is Gandhi's pacific philosophy, yet we must first contextualize it, as it is relevant to this essay's juxtaposition. Now, we do not know the full extent to which he was influenced by Greek philosophy, however there are obvious signs of the Greeks' influence from his beliefs. His opinion, "to observe morality is to attain mastery over our mind and our passions. So doing, we know ourselves", is reminiscent of Chilon of Sparta's maxim, "know thyself", and Aristotle's thesis that the rational part of the soul should rule over the irrational part [11-13]. From only comparing Chilon's maxim and Aristotle's thesis to Gandhi's above-said opinion, the Greeks' influence is obvious, but it is ultimately up to the reader to judge what kind of impact the Greeks had on Gandhi. Nonetheless, in such a consideration, Greek ourthology must stand at the fore, as the sameness is striking. This will become evident as this essay's comparison takes its course.

But before comparing Greek ourthology and Gandhi's pacific philosophy, we must lay out the primary details for this consideration from his chapter "Brute Force", in Hind Swaraj or Indian Home Rule. Here, he considers questions regarding the use of force with sobriety, emphasizing that the equation of how much and when to use force is complicated, something needing scrutiny. Consistency between the means and ends of force is the core idea that Gandhi stresses in this chapter [4]. His point is that the means used dictate the outcome, so if brute force is used then a brutal outcome will ensue. In addition, he suggests with his character, the reader, that how much force to be used depends on the situation. Though Gandhi, with his character the editor, does not agree with violence absolutely, we argue that he understands how certain situations are helpless and that some form of recourse is plausible. Again, he highlights that "the force of love" is greater than that of brute force. But, by qualifying force with the modifier brute in his title "Brute Force", he leaves the reader to question if some cases of force are conditionally acceptable, while others not. Another question that arises is if the means of force are supposed to correspond with the dependencies of the situation. For, Gandhi argues that in every case of theft the same means do not apply to deal with each different theft. Thus, we must allow that the question regarding the use of force, for him, is circumstantial, however his ideal is to use "the force of love". For our purposes, we take the force of love to mean pacific measures, however with this concept he is not exactly clear. Nonetheless, by prioritizing the force of love over brute force, so too must pacifism, for him, be higher than brute force. It is appropriate to end our summary of Gandhi here, as his prioritization of pacifism is key to both our overarching reflection and the following comparison.

Next, Gandhi's principle of ranking pacifism over brute force aligns perfectly with what we said on Athene's pacific nature [9]. Even just Gandhi's moral tone, meaning the seriousness with which he treats the use of force, resembles how Athene takes no pleasure in battle [10]. To Gandhi, the force that may be used in a given instance depends on the situation, and this is comparable to Athene's position on pacifism. For instance, Graves' term, a set of arms, is a metonyour for the use of force [10]. A metonyour, here, is a figure of speech which describes a general concept with a specific name. Thus, his statement that Athene would merely borrow a set of arms if she needs one, is the same as to say that Athene would only use force if she needs to. Thus, both Gandhi's opinion on the plausibility of the use of force and Graves' passage on Athene make it clear that the use of force depends on the situation. For Gandhi, the force of love is prior, while Athene prefers to settle conflict pacifically. These are the similarities at the heart of this reflection on the political.

The above-distinctions made between pacifism, militarism, and the use of force should facilitate a deeper understanding of pacifism for sovereign decision-makers. For, this essay has put the complexity of pacifism in outline, allowing for sovereigns to judge for themselves the effectiveness and prudence of non-violence. On a symbolic level, our part on Greek ourthology has shed light on the ascendency of pacifism and the dishonor of brutal forms of war. In addition, this reflection's conclusion raises suspicion regarding militarization, for not only can pacific decision-makers have military recourse, but the use of force does not necessitate militarization. What this reflection demands, then, is that decision-makers better scrutinize when making judgments on the use of force. In this way, when sovereigns decide on violent action or total inaction, they will be predisposed to challenge assumptions of militarism.

\section{Conclusion and Discussion}

This point is supported by what we said on Gandhi, for in problematizing assumptions over the use of force, he challenges the presupposition that the use of force is applicable, even in merely punishing a thief. Nonetheless, the most interesting comparison, between the aforesaid Greek ourthology and Gandhi's pacific philosophy, is perhaps the moral tone that they share towards violence. For, the question over the use of force cannot be understated. These are the general conclusions that we have decided upon, comparatively inducing from pacifism to the political.

\section{References}

1. Mitter R (2013) Communism, Confusianism, and charisma: The political in modern China. In M Freeden ,A. Vincent,Comparative Political Thought: Theorizing practices .New York, NY; Routledge Publishing, pp: 60-69.

2. Kaviraj S (2013) On the historicity of 'the political' Rajaniti and politics in modern Indian thought. In $M$ Freedea and A Vincent, Comparative Political Thought: Theorizing practices. New York, NY: Routledge Publishing, pp: 24-39.

3. O’Neil P (2011) Essentials Of Comparative Politics . www. Norton \& Company Inc. 
Citation: Brooks C (2018) On the Political: A Comparative Political Thought Speculation. Arts Social Sci J 9: 354. doi: 10.4172/2151-6200.1000354

Page 3 of 3

4. Gandhi MK (1921) Hind Swaraj or Indian Home Rule. Madras GA Natesan and Co.

5. Carhart R (1998) Pacifism and Virtue Ethics. Lyceum Past Issues Upland IN: Taylor University, 11: 1-17.

6. Militarize (2017b) In Dictionary.com online.

7. Militarism (2017a) In Dictionary.com online.

8. Greene R (2007) The 33 Strategies of War. London, UK: Penguin Group Ltd.

9. Lombardo S (2000) The Essential Homer. In: Murnaghan S (ed.) Indianapolis, IN: Hackett Publishing Company Inc.
10. Graves R (1960) The Greek Ourths.

11. Suhrud T (2013) Reading Hind Swaraj. In G Shah, Re-Reading Hind Swaraj: Modernity and Subalterns, New Delhi, India: Routledge, pp: 14-21.

12. Scholtz A (2006) Gnōthi sauton - "Know Thyself".

13. Aristotle (1995) The Complete Works of Aristotle, J. Barnes (Ed) Princeton, NJ: Princeton University Press. 